\title{
Study of relationship between obesity and executive functions among high school students in Bushehr, Iran
}

\author{
Soqra Ebrahimi Qavam ${ }^{1}$, Abbas Anisan², Marjan Fathi ${ }^{3}$ and Ata Pourabbasi ${ }^{4 *}$
}

\begin{abstract}
Background: Obesity is one of the most challenging problems of public health in the present century and can have some serious impacts on cognitive abilities in children and adolescents. This study has tried to investigate the relationship between obesity and executive functioning, particularly in planning- organizing and problem solving among a group of adolescents.

Methods: Some 120 male high school students in the 15 to 18 year age range were included. BMI and executive functions were measured with validetes tools and tests in cases.

Results: There is a significant difference between the executive functions such as planning-organizing and problem solving in obese, overweight and normal students.

Conclusions: According to our results it seems the obese adolescents have poorer executive functions than normal weight peers. This is important for families and school staff to design and follow some therapeutic plans for weight reduction in adolescents in order to help them improve their skills in some functions such as planning-organizing and problem solving.
\end{abstract}

Keywords: Aobesity, Adolescents, Executive functions, Cognition

\section{Introduction}

Obesity as a widespread and prevalent disorder is causally associated with critical illnesses [1] and is one of the most challenging problems of public health in the present century. In addition, It is the most common nutrition - health problem in developed and developing countries which has great impact on many aspects of individuals and communities [2].

In general, the involvement of the health sector in the increasing incidence of complications remains relatively large yet, [3] including diabetes, coronary heart disease, hypertension, cerebrovascular diseases etc. [4]

According to Farzadfar et al. study on the epidemiology of obesity in 199 countries in 2008, there are 1.46 billion overweight and 502 million obese people in the

\footnotetext{
* Correspondence: atapoura@gmail.com

${ }^{4}$ Diabetes Research Center, Endocrinology and Metabolism Clinical Sciences Institute, Tehran University of Medical Sciences, 5th Floor, Sharitai Hospital, North Kargar Ave, Tehran, Iran

Full list of author information is available at the end of the article
}

world. [5] In Iran, approximately $19.4 \%$ of adults are obese and $51.4 \%$ are overweight.

Obesity is also linked to adverse neurodevelopmental outcomes such as degeneration of the frontal cortex and white matter brain damage [6]. In addition, recent studies have pointed to the link of obesity with poor cognitive functions [7]. Several studies have also reported degrees of cognitive vulnerability in obese subjects, including impairments in reaction time, alertness and attention, as well as immediate word recall, delayed recall, selective attention, processing speed and executive functioning, implicit memory, semantic memory and spatial abilities [8].

Executive functioning refers to a set of cognitive processes addressing the management of targeted behavior [9]. This ability is associated with the frontal lobe of the brain and the development of the prefrontal brain [10].

There are some controversies on whether the components of the executive functioning are affected by overweight and obesity in adolescents. This study has tried 
Table 1 Demographic characteristics of samples of different groups

\begin{tabular}{|c|c|c|c|c|c|c|c|}
\hline \multirow{2}{*}{$\begin{array}{l}\text { Demographic } \\
\text { characteristics }\end{array}$} & \multirow[t]{2}{*}{ Groups } & \multicolumn{2}{|l|}{ Obese } & \multicolumn{2}{|c|}{ Overweight } & \multicolumn{2}{|l|}{ Normal } \\
\hline & & Number & Percent & Number & Percent & Number & Percent \\
\hline \multirow[t]{3}{*}{ School Grade } & Junior high school & 13 & 32.5 & 12 & 30 & 12 & 30 \\
\hline & second-grade high school & 13 & 32.5 & 15 & 37.5 & 14 & 35 \\
\hline & third-grade high school & 14 & 35 & 13 & 32.5 & 14 & 35 \\
\hline \multirow[t]{4}{*}{ Age } & 15 years & 14 & 35 & 13 & 32.5 & 12 & 30 \\
\hline & 16 years old & 13 & 32.5 & 13 & 32.5 & 14 & 35 \\
\hline & 17 years & 11 & 27.5 & 14 & 35 & 12 & 30 \\
\hline & 18 years & 2 & 5 & 0 & 0 & 2 & 5 \\
\hline
\end{tabular}

to investigate the relationship between obesity and executive functioning, particularly in planning- organizing and problem solving among a group of adolescents in Iran.

\section{Materials and methods}

Human subjects approval statement

This project was approved by the Ethical Board Committee of the Endocrinology and Metabolism Research Institute in accordance with Helsinki declaration and the guidelines of the Iranian Ministry of Health and Medical Education. All the students agreed to participate in the study.

\section{Participants}

This observational study was carried out on 120 male high school students in the range of 15 to 18 year age including three groups of obese, overweight and normal students in Bushehr province of Iran in 2014.

\section{Measurement tools}

\section{Body mass index}

The weight was measured at the minimum coverage and without shoes using a digital scale with a precision of $100 \mathrm{~g}$. The height was measured via a stadiometer. The body mass index (BMI), the most commonly accepted index, was calculated to estimate obesity [11]. Based on the charts of the Reference Center for Disease Control, those having a BMI equal to or greater than the $95^{\text {th }}$ percentile for age and gender were considered as obese, and a BMI between 85 and 95 percentile for age and sex were taken as overweight [12].

\section{Andre Rey test}

Planning and organizing functions were measured by Andre Rey Test, which is standardized by Mir Hashemi in Iran [13]. The Test consisted of two cards, A and B, which were selected separately and in accordance with the situation. Card A included 18 cognitive components used for people aged four and older. The Effective performance of the card is for Seven year old children and older and more practical for teens and adults. [14].

\section{Tower of London Test}

It is the most famous test for the calculation of planning and problem solving. A computerized variant of this test was developed by Morris in which the vertebral ring with three-dimensional structure has been administered [15]. Two-tier arrangement is shown to participants on a screen touch computer. In each trial, top row remains constant and shows the arrangement of the target. The bottom row contains a loop that participants should rearrange it, so that it should match with the upper-tier arrangement. Target for the loop is variable, but the starting point is fixed. Minimum gestures through which the participants can solve the problem are 2, 3, 4, 5 movements [16]. Variables include total score, total run

Table 2 Descriptive characteristics of variables in obese, overweight and normal group

\begin{tabular}{|c|c|c|c|c|c|c|c|c|c|}
\hline \multirow{2}{*}{$\begin{array}{l}\text { Groups } \\
\text { Variables }\end{array}$} & \multicolumn{3}{|l|}{ Obese } & \multicolumn{3}{|c|}{ Overweight } & \multicolumn{3}{|l|}{ Normal } \\
\hline & Numbers & $M^{a}$ & $S D^{b}$ & Numbers & M & SD & Numbers & M & SD \\
\hline Planning- organizing first stage & 40 & 35.15 & 1.05 & 40 & 35.85 & 1.08 & 40 & 35.77 & 1.26 \\
\hline Planning- organizing second stage & 40 & 21.47 & 4.85 & 40 & 25.13 & 4.73 & 40 & 29.36 & 4.23 \\
\hline Tower of London total score & 40 & 24.98 & 3.15 & 40 & 27.33 & 3.11 & 40 & 30.78 & 3.87 \\
\hline Tower of London runtime & 40 & 440.90 & 176.57 & 40 & 387.25 & 165.57 & 40 & 275.07 & 149.57 \\
\hline Tower of London copy time & 40 & 305.87 & 135.57 & 40 & 276.35 & 115.56 & 40 & 194.32 & 133.56 \\
\hline Tower of London errors & 40 & 24.27 & 5.60 & 40 & 20.50 & 4.60 & 40 & 11.82 & 4.30 \\
\hline
\end{tabular}

${ }^{\mathrm{b}}$ standard deviation 
Table 3 Kolmogorov-Smirnov one-sample test

\begin{tabular}{llll}
\hline Statistics & $Z$ & $P$ & Significance level \\
Variables & & & \\
\hline Planning-organizing first stage & 0.83 & 0.51 & 0.05 \\
Planning-organizing the second stage & 1.22 & 0.09 & 0.05 \\
Tower of London total score & 1.24 & $0 / 09$ & $0 / 05$ \\
Tower of London runtime & 1.07 & 0.19 & 0.05 \\
Tower of London copies & 1.21 & 0.11 & 0.05 \\
Tower of London errors & 1.25 & 0.09 & 0.05 \\
\hline
\end{tabular}

time, copy time and the number of errors [15]. The Correlation between the results of the test and Porteus Mazes has been reported as $r=0.41$ [17]. The validity of test (0.97) is accepted [18].

\section{Results}

Students were matched according to their age, education and gender for the comparison of the executive functioning.

Descriptive parameters including frequency and percentage of subjects in each grade and age group are presented in Table 1 . The mean and standard deviation (SD) in different groups of participants, Andrea Ray, Tower of London Tests are shown in Table 2.

Assumed to be normal, the distribution was examined by using the Kolmogorov-Smirnov one-sample test, and statistical significance of each variable was attained. Each variable was greater than 0.05 and the data on all variables were normal. (Table 3 )

The homogeneity of variances was examined using Levine test. The significance level of the F-statistic in Levine test for London Bridge was greater than 0.05, so there was no significant difference between the group variance in the dependent variable which contributed to meeting the assumption of homogeneity of variances. The test statistics for Andre Ray is also greater than 0.05 , Thus the analysis of homogeneity of variance test was performed in both groups and the results confirmed the assumptions. (Table 4)

After ensuring that all analyzed data were eligible using the analysis of variance, the test was performed.
The multivariate analysis of variance was applied in order to compare the three groups in Planning Organization (Andre Rey test) and the solution (the Tower of London test). The results are reported In Tables 5 and 6.

The obese, overweight and normal groups were compared using an Andre Ray test. The results of this analysis (Lambda $=0.48$, Vickles, $0.05>$ P, F $(226,10)-10 / 05)$, revealed the role of weight as an effective factor. These findings raised the issue that at least one component among three groups is different. The effect of weight for planningorganizing at the first and second stages is 0.15 and 0.13 , which means that $15 \%$ and $13 \%$ of the variance of individual differences is related to weight. In addition, the statistical analysis suggested that the probability of correctly rejecting the null hypothesis of the test is at least $98 \%$.

Table 6 shows the comparison of obese, overweight and normal subjects using the Tower of London. Considering the results of our analyses (Vickles Lambda $=0.43, p<05 / 0$, $98 / 14=$ F (8 and 228) a significant effect of weight is appeared. These results indicated that at least one component of the problem solving (total score, runtime, copy and error) has some differences among normal, overweight and obese subjects. Afterwards, the significance level for each four problem solving subscales was obtained which was lower in comparison with which was obtained from the modified Bonferrony correction as 0. 15 (significance level split 0.05 of the 4 components of the problem solving).

In addition, the statistical analysis in this study suggested that the probability of the correctly rejection of the null hypothesis is at least $99 \%$. In order to accurately assess the difference between the three groups, the outcomes of the Tukey test showed that there is a significant difference in the total score of error and the numbers of subscales between the three groups.

\section{Discussion}

In this study, we investigated the components of executive functioning, including planning-organizing and problem solving in obese, overweight and normal students. The results showed that there is a significant difference between the executive functions such as planning-organizing and problem solving in obese,

Table 4 Levine F test for homogeneity of variance in three research groups

\begin{tabular}{lllllll}
\hline $\begin{array}{l}\text { Variables } \\
\text { Index }\end{array}$ & $\begin{array}{l}\text { Tower of } \\
\text { London errors }\end{array}$ & $\begin{array}{l}\text { Tower of } \\
\text { London copies }\end{array}$ & $\begin{array}{l}\text { Tower of } \\
\text { London run-time }\end{array}$ & $\begin{array}{l}\text { Tower of } \\
\text { London Total score }\end{array}$ & $\begin{array}{l}\text { Planning, organizing } \\
\text { the second round }\end{array}$ & $\begin{array}{l}\text { Planning, organizing } \\
\text { the first stage }\end{array}$ \\
\hline $\mathrm{df1}^{\mathrm{a}}$ & 2 & 2 & 2 & 2 & 2 & 2 \\
$\mathrm{df2}$ & 117 & 117 & 117 & 117 & 0.02 & 117 \\
$\mathrm{~F}$ & 0.77 & $2 / .1$ & 0.35 & $0 / 18$ & 0.94 & 0.05 \\
$\mathrm{sig}$ & 0.46 & 0.06 & 0.70 & 0.83 & 0.91 \\
\hline
\end{tabular}


Table 5 MANOVA and ANOVA test text

\begin{tabular}{llrlrrrr}
\hline $\begin{array}{l}\text { Statistical Indicators } \\
\text { Variables }\end{array}$ & $\begin{array}{l}\text { Change } \\
\text { sources }\end{array}$ & \multicolumn{1}{l}{$\mathrm{Ss}^{\mathrm{a}}$} & $\mathrm{df}$ & $\mathrm{F}$ & Significance level & Effect size & Power of test \\
\hline Planning, organizing first phase & group & 11.81 & 2 & 10.60 & 0.001 & 0.15 & 0.98 \\
Planning, organizing the second phase & group & 1246.36 & 2 & 38.65 & 0.001 & 0.39 & 0.99 \\
\hline
\end{tabular}

${ }^{\mathrm{a}}$ sum of squares

overweight and normal students. These results are consistent with the findings of previous studies [7, 8, 19-27].

Fergenbaum et al. examined whether obesity is a predictor of decreased executive functioning and found out that poor performance of executive functions in obese people are five times more likely than healthy ones.[21] Also Fitzpatrick et al. in their study showed that obese individuals were weaker in decision-making, planning and problem solving compared to their normal weight peers [22]. However, MacGregor et al. showed in their study that there is no significant relationship between the obesity and cognitive functions after controlling for the relevant variables [28].

There are numerous definitions for executive functioning which include elements such as planning and purposeful, organized behavior over time, response inhibition, attention, working memory, self regulation processes, selfcontrolling and self monitoring [29]. These skills develop from childhood to adolescence and even to adulthood [30].

The above results can be explained by the relationship between obesity and adverse neurodevelopmental outcomes such as degeneration of the frontal cortex and white matter [6]. In fact, the underlying causes of obesity can be associated with the limbic neural circuitry destruction of orbital frontal cortex [31]. Since the ability of executive functioning is a part of the superior prefrontal cortex activity, it's generally believed that the impairment or dysfunction of the prefrontal areas and some areas of the cerebral cortex are significantly associated with the student's ability to perform executive functions [32]. Accordingly, it appears that the orbital frontal cortex and limbic circuit are associated with the prevention or reduction of the executive functions [33].

There are some possible biological mechanisms for the relationship between obesity and structural changes of the brain and its relevance with poor executive function.
Obesity is highly correlated with the many changes that potentially can have a negative impact on cognitive functions like vascular changes such as thickening and hardening of the brain arteries, impaired insulin regulation, inflammation, cardiovascular disorders etc. [23].

Although the increased body mass index is along with decreased cognitive and executive functions, especially in the field of memory and executive functioning, problem solving and planning [7], but individuals with poor and impaired executive functioning are more likely to be overweight or obese. This may be due to the fact that many aspects of executive functioning such as impulse control, self and goal-oriented behavior is directly related to the ability to maintain energy balance [23].

The authors encountered some limitations in this study. The bureaucratic processes in the school setting hindered the cooperation of its administrators with researchers. On the other hand, considering that the evaluation of executive functions is still a new field in Iran and therefore few Persian literature are available. This study contains only two domains of executive functioning, including planning- organizing and problem solving in the Forum. We highly suggest that future researches also examine other executive functions among obese individual.

\section{Conclusion}

According to our results, it can be concluded that the obese adolescents have poorer executive functions than normal weight peers. This is important for families and school staff to design and follow some therapeutic programs and interventions for weight reduction in adolescents in order to improve the executive functioning in them with the emphasis on the education of thinking and problem solving skills.

Table 6 MANOVA and ANOVA test

\begin{tabular}{|c|c|c|c|c|c|c|c|}
\hline $\begin{array}{l}\text { Statistical Indicators } \\
\text { Variabes }\end{array}$ & Change resource & $\mathrm{SS}^{\mathrm{a}}$ & $d f$ & $\mathrm{~F}$ & Significance level & Effect size & Power of test \\
\hline The Tower of London Total & Group & 680.86 & 2 & 41.54 & 0.001 & 0.41 & 0.99 \\
\hline the Tower of London Runtime & Group & 572793.12 & 2 & 18.52 & 0.001 & 0.24 & 0.99 \\
\hline the Tower of London Copy time & Group & 267243.05 & 2 & 13.95 & 0.001 & 0.19 & 0.99 \\
\hline Tower of London Number of errors & Group & 3260.12 & 2 & 55.25 & 0.001 & 0.48 & 0.99 \\
\hline
\end{tabular}




\section{Competing interests}

The authors declare that they have no competing interests.

\section{Authors' contributions}

SEQ supervised the project and help selecting and running cognitive tests, AA carried out the measurements and tests, MF help desiging reports and scientific writing and AP developed main idea and advised in case finding and assessments. All authors read and approved the final manuscript.

\section{Author details}

${ }^{1}$ Faculty of psychology and education, Allameh Tabatabaee University, Tehran, Iran. ${ }^{2}$ Allameh Tabatabaee University, Tehran, Iran. ${ }^{3}$ Islamic Azad University, Kish Branch, Iran. ${ }^{4}$ Diabetes Research Center, Endocrinology and Metabolism Clinical Sciences Institute, Tehran University of Medical Sciences, 5th Floor, Sharitai Hospital, North Kargar Ave, Tehran, Iran.

Received: 30 July 2015 Accepted: 6 October 2015

Published online: 15 October 2015

\section{References}

1. Allison DB, Fontaine KR, Manson JE, Stevens J, Vanltallie TB. Annual deaths attributable to obesity in the United States. JAMA. 1999;282(16):1530-8.

2. Kelly T, Yang W, Chen CS, Reynolds K, He J. Global burden of obesity in 2005 and projections to 2030. Int J Obes (Lond). 2008;32(9):1431-7.

3. Noori R, m.M.a.M.F. Prevalence of overweight and obesity associated with lifestyle and level of physical fitness in adults in Shiraz. J Endocrinol Metabol. 1391;14(3):8.

4. Pi-Sunyer $X$. The medical risks of obesity. Postgrad Med. 2009;121(6):21-33.

5. Farzadfar F, Danaei G, Namdaritabar H, Rajaratnam JK, Marcus JR, Khosravi A, et al. National and subnational mortality effects of metabolic risk factors and smoking in Iran: a comparative risk assessment. Popul Health Metr. 2011;9(1):55.

6. Whitmer RA, Gunderson EP, Barrett-Connor E, Quesenberry CP Jr, Yaffe K. Obesity in middle age and future risk of dementia: a 27 year longitudinal population based study. BMJ. 2005;330(7504):1360.

7. Boeka AG, Lokken KL. Neuropsychological performance of a clinical sample of extremely obese individuals. Arch Clin Neuropsychol. 2008:23(4):467-74.

8. Nilsson LG, Nilsson E. Overweight and cognition. Scand J Psychol. 2009;50(6):660-7.

9. Locascio $\mathrm{G}$ et al. Executive dysfunction among children with reading comprehension deficits. J Learn Disabil. 2010;43(5):441-54.

10. $H, A$. Executive functions in relation to developmental disorders and cognitive neuropsychology. Cognitive Sci News. 1385;8(4):14.

11. Keshavarz A, H.N.A, Mirzaie K. Endocrinology and Genetics adipose tissue. $1^{\text {st }}$ ed. Tehran: Yaranemehr publisher; 1389.

12. Kuczmarski RJ, Ogden CL, Grummer-Strawn LM, Flegal KM, Guo SS, Wei R, et al. CDC Growth Chart. United States: Adv Data; 2000.

13. $\mathrm{M}, \mathrm{M} . \mathrm{H}$. The standardization of the test images Andre Rey $7-15$ and adult students in Tehran. In: Psychology. Tehran: Islamic Azad University; 1371.

14. H, B. Psychological tests (theoretical principles and techniques). Tehran: AllamehTabatabai University Press; 1381.

15. Morris RG, Ahmed S, Syed GM, Toone BK. Neural correlates of planning ability: Frontal lobe activation during the tower of London test. Neuropsychologia. 1993;31(12):1367-78.

16. Morris RG, Rushe T, Woodruffe PW, Murray RM. Problem solving in schizophrenia: a specific deficit in planning ability. Schizophr Res. 1995;14(3):235-46.

17. Krikorian R, Bartok J, Gay N. Tower of London procedure: a standard method and developmental data. J Clin Exp Neuropsychol. 1994;16(6):840-50.

18. Lezak MD, H., D.B, Loring DW. Neuropsychological Assessment. $4^{\text {th }}$ ed. New York: Oxford University Press; 2004.

19. Duchesne $M$ et al. Assessment of executive functions in obese individuals with binge eating disorder. Rev Bras Psiquiatr. 2010;32(4):381-8.

20. Elias SM. Anti-Intellectual Attitudes and Academic Self- Efficacy Among Business Students. J Educ Business. 2008;84(2):110-117.

21. Fergenbaum JH, Bruce S, Lou W, Hanley AJ, Greenwood C, Young TK. Obesity and lowered cognitive performance in a Canadian First Nations population. Obesity (Silver Spring). 2009;17(10):1957-63.

22. Fitzpatrick S, Gilbert S, Serpell L. Systematic review: are overweight and obese individuals impaired on behavioural tasks of executive functioning? Neuropsychol Rev. 2013;23(2):138-56.
23. Gunstad J, Paul RH, Cohen RA, Tate DF, Spitznagel MB, Gordon E. Elevated body mass index is associated with executive dysfunction in otherwise healthy adults. Compr Psychiatry. 2007:48(1):57-61.

24. Gustafson DR, Steen B, Skoog I. Body mass index and white matter lesions in elderly women. An 18-year longitudinal study. Int Psychogeriatr. 2004;16(3):327-36.

25. Sabia S, Kivimaki M, Shipley MJ, Marmot MG, Singh-Manoux A. Body mass index over the adult life course and cognition in late midlife: the Whitehall II Cohort Study. Am J Clin Nutr. 2009;89(2):601-7.

26. Volkow ND, Wang GJ, Telang F, Fowler JS, Goldstein RZ, Alia-Klein N et al. Inverse association between BMI and prefrontal metabolic activity in healthy adults. Obesity (Silver Spring). 2009;17(1):60-5.

27. Waldstein SR, Katzel LI. Interactive relations of central versus total obesity and blood pressure to cognitive function. Int J Obes (Lond). 2006;30(1):201-7.

28. MacGregor, Kristin. Obesity Indices and Cognitive Function in Veterans, in Graduate School 2012, psychology dissertation, Syracuse University, Paper 177.

29. McCloskey G, P.L.A, Van Divner B. Assessment and intervention for executive function difficulties. New York: Taylor \& Francis Group; 2009.

30. Steins CM. Disorganized children, A Guide for parents and professionals. 1 ed. 2006: Jessica Kinsley publisher.

31. Willeumier KC, Taylor DV, Amen DG. Elevated BMI is associated with decreased blood flow in the prefrontal cortex using SPECT imaging in healthy adults. Obesity (Silver Spring). 2011;19(5):1095-7.

32. J.M, F. The Prefrontal Cortex. New York: Academic; 2008.

33. Cohen Jl, Yates KF, Duong M, Convit A. Obesity, orbitofrontal structure and function are associated with food choice: a cross-sectional study. BMJ Open. 2011;1(2):e000175.

\section{Submit your next manuscript to BioMed Central and take full advantage of:}

- Convenient online submission

- Thorough peer review

- No space constraints or color figure charges

- Immediate publication on acceptance

- Inclusion in PubMed, CAS, Scopus and Google Scholar

- Research which is freely available for redistribution 